\title{
Lexical Causatives in Modern English: On Classification of Kill-Verbs
}

\author{
Robert Khachatryan \\ Yerevan State Linguistic University
}

$\mathbf{T}$ he notion of cause is an indivisible part of human cognition and language. The majority of actions and happenings are interconnected and interdependent. One event can usually be a cause for another one. This phenomenon is called causation, i.e. a relation between situations (events). The notion of causation finds its expression at the linguistic level, incorporating special structures and meanings. Situations that include the notion of causation are comprised of actions rather than states. Some actions not only execute the meaning they denote, but initiate a single or series of further actions as well. To put it differently, causation is "some relation of determination between two events, with a prior event resulting in or giving rise to a subsequent event" (Frawley 1992:158). Accordingly, causation and its means of expression in language constitute a significant area in linguistics.

The objective of this article is to reclassify lexical causatives (also known as covert or underived causatives), namely verbs of killing or kill-verbs, formerly classified by Levin (1993) and Lemmens (1998). The method of suggested classification is to categorize kill-verbs according to the instrument (if the instrument of killing is mentioned or embedded in the definition), the motivation (if special reasons for killing are mentioned or embedded in the definition), and the manner (if the special way of killing is mentioned or embedded in the definition). The new classification elaborates on the expression of the nuclear meaning "to cause to die" and the features of kill-verbs on periphery, and it also introduces more decisive criteria for categorizing the subgroup of lexical causatives, i.e. kill-verbs. Furthermore, verbs with the most frequent occurrences in speech are studied on the basis of linguistic data from the British National Corpus (the BNC), which may entail discern patterns of usage and semantic differences. Moreover, as words may acquire a broader meaning and usage in fiction, especially when used in metaphors, cases of metaphoric use of kill-verbs have not been considered.

The notions of cause and effect in Modern English may either be expressed morphologically, syntactically or lexically (Khachatryan 2009). First two types of causatives are formed with the help of affixes and auxiliary verbs respectively, while lexical causatives do not embed any affixes or auxiliary words. They incorporate the meanings of both cause and effect in the root morpheme. Thus, lexical causatives are underived and embed the meaning of causation in their semantics. The majority of lexical causatives form causative alternations with their counterparts, called anticausatives (Dowty 1979:40). The causatives express the cause and the effect at the same time, while the anti-causatives refer only to the effect, i.e. the result of the action, and are devoid of any causative meaning. Some of the non-causatives embrace dissim- 
ilar stems, for example to kill - to die, to feed - to eat, to teach - to learn. Others differ in vowel alternations, like to rise - to raise, to lay - to lie. Further on, the majority of causative alternations differ on the grounds of transitivity/intransitivity, for instance to change (transitive) - to change (intransitive), to open (transitive) - to open (intransitive), to stop (transitive) - to stop (intransitive), to smash (transitive) - to smash (intransitive), etc.

Unlike syntactic and morphological causatives, lexical causatives stand on a completely different platform due to two features. First, they bear the meaning of causation from within; hence, these verbs are always causative even though they can sometimes be used in non-causative constructions. This may be illustrated with the lexical causative verb to kill, which has the nuclear meaning of "to cause to die". In the example Charlie killed the goat with his blade. $\Rightarrow$ Charlie caused the goat to die. The verb to kill expresses the actual act of killing, i.e. Charlie intentionally caused the goat to die by undertaking certain actions, namely cutting the throat of the goat. Whereas, in the example Charlie was devastated and ready to kill, the verb to kill is used as an infinitive to express the agent's ability and readiness, not causation. This is due to the fact that minimum two participants, causer and causee, are required in causative relations to indicate the causeeffect relationship. Thus, in the first example we observe the cause-result, while the second illustrates the event without result.

Levin and Lemmens introduce classifications of kill-verbs to better conceptualize their semantic characteristics. To start with, Levin (1993) presents two categories of kill-verbs: murder- and poison-verbs. Her main criterion for such classification is embedded in the way of killing. In the Murder category, verbs express intentional killing but "none of the verbs in this class lexicalizes a means component; that is, none provides any information about how the killing came about" (Levin 1993:231), while in the case of Poison-verbs the means of killing is incorporated in the semantics of the verb. She posits, "some of poison verbs are not exclusively verbs of killing, since they describe actions that have death as only one of their possible results" (Levin 1993:233).

\begin{tabular}{|l|l|}
\hline Category & $\underline{\text { Kill-verbs }}$ \\
\hline Murder verbs & $\begin{array}{l}\text { assassinate, butcher, dispatch, eliminate, execute, immolate, kill, } \\
\text { liquidate, massacre, murder, slaughter, slay }\end{array}$ \\
\hline Poison verbs & $\begin{array}{l}\text { asphyxiate, crucify, drown, electrocute, garrotte, hang, knife, } \\
\text { poison, shoot, smother, stab, strangle, suffocate }\end{array}$ \\
\hline
\end{tabular}

Lemmens (1998) argues the Levin's classification, particularly the category of Poison-verbs, pointing out the heterogeneity of the group and suggesting re-classification by emphasizing the semantics of the verbs, ignored by Levin. Additionally, Lemmens (1998:56) criticizes the cross-classification employed by Levin to highlight the Suffocate-verbs. Instead, Lemmens presents his own classification with six categories. 


\begin{tabular}{|l|l|}
\hline Category & Kill-verbs \\
\hline Murder-verbs & $\begin{array}{l}\text { assassinate, butcher, execute, kill, lynch, massacre, murder, } \\
\text { slaughter, slay, }\end{array}$ \\
\hline Suffocate-verbs & $\begin{array}{l}\text { asphyxiate, choke, drown, smother, stifle, strangle, suffocate, } \\
\text { throttle }\end{array}$ \\
\hline Starve-verbs & famish, starve \\
\hline Instrument-verbs & crucify, garrote, knife, poison \\
\hline Action-verbs & hang, shoot, stab \\
\hline Decapitate-verbs & behead, decapitate \\
\hline
\end{tabular}

Lemmens treats these six categories as flexible and expansive towards new kill-verbs, but leaves out the verb to electrocute (to injure or kill by electric shock). In this context, Lemmens mainly discusses the Instrument-verbs, considering the inclusion of any verb that incorporates the idea of killing and its possible instrument. He illustrates his point with the example I am sure going to be chaired, which denotes killing via an electric chair (Lemmens 1998:57). Lemmens also pays attention to the transitivity/ergativity of kill-verbs, classifying the murder-, instrument- and decapitate-verbs under the category of transitivity and grouping the verbs: to starve and suffocate (with the exception of strangle, throttle, and smother) as ergative (Lemmens 1998:59).

Although Levin and Lemmens elaborate on the idea of general definition ("to cause to die"), they do not reflect on it as a nuclear criterion for classification. Lemmens chooses kill-verbs for analysis based on their frequency of use in speech, but does not connect it to the hierarchy of nuclear features of kill-verbs. Taking into account the previous classifications of kill-verb, this article suggests a new classification, based on three features of these verbs: the instrument, stimulus, and manner. The main criteria employed for the classification are the nuclear meaning "to cause to die" and the occurrence of additional features in definitions, crosschecked in Oxford English Dictionary (OED) and Longman Dictionary of Contemporary English (LDOCE).

\begin{tabular}{|c|c|c|c|}
\hline \multicolumn{3}{|c|}{$\frac{\text { Nuclear meaning }}{\text { (to cause to die) }}$} & \multirow[b]{2}{*}{$\begin{array}{l}\text { Verbs on Periphery } \\
\text { dispatch, eliminate, } \\
\text { exterminate, liquidate }\end{array}$} \\
\hline $\begin{array}{l}\text { Instrument features } \\
\text { drown, garrote, } \\
\text { hang, knife, poison, } \\
\text { stab, shoot }\end{array}$ & $\begin{array}{c}\text { Motivation } \\
\text { (stimulus) features } \\
\text { assassinate, execute, } \\
\text { lynch, martyr }\end{array}$ & $\begin{array}{l}\text { Manner features } \\
\text { asphyxiate, behead, } \\
\text { butcher, choke, } \\
\text { crucify, decapitate, } \\
\text { famish, massacre, } \\
\text { slaughter, slay, } \\
\text { smother, starve, } \\
\text { stifle, strangle, } \\
\text { suffocate, throttle }\end{array}$ & \\
\hline
\end{tabular}


The verbs directly relating to the nuclear meaning are to kill (to cause the death of a person or other living thing) and to murder (to conduct the unlawful premeditated killing of one person by another). These verbs denote the nuclear meaning "to cause to die" without any additional information on the instrument, motivation or manner. Therefore, the most expedient method of classification of kill-verbs is to categorize them according to the instrument (if the instrument of killing is mentioned or embedded in the definition), the motivation (if special reasons for killing are mentioned or embedded in the definition), and the manner (if the special way of killing is mentioned or embedded in the definition).

The first subcategory, the instrument features, includes the following verbs:

- garrotte (to kill by strangulation, especially with a length of wire or cord),

E.g. "Did you know you can garrotte someone in a few seconds?" (BNC 2007:H90 1930)

- $\quad s t a b$ (to thrust a knife or other pointed weapon into someone so as to kill),

E.g. "What sort of a person would stab a child to death?" (BNC 2007:ANL 589)

- $\quad$ shoot (to kill a person or animal with a bullet or arrow),

E.g. Two children have witnessed their father shoot their mother then commit suicide at a house in London. (BNC 2007:K1T 1835)

- knife (to stab someone with a knife),

E.g. The victims had been knifed more than seventy times. (BNC 2007:CEN 3338)

- poison (to administer poison to a person or animal),

E.g. "Her sister, Goneril, who has poisoned her, isn't surprised: 'If not, I'll ne'er trust medicine." (BNC 2007:BNH 643)

- hang (to kill someone by tying a rope attached from above around their neck),

E.g. "He hung himself in his cell three months after the trial." (BNC 2007:GUU 2984)

- drown (to kill a person or animal by submerging under water or other liquid).

E.g. "He had drowned himself in the Rectory pond." (BNC 2007:AB4 834)

E.g. Owen Lloyd, a nine-year-old boy, drowned a four-year old friend. (BNC 2007:H7A 1496)

The verb crucify (to put someone to death by nailing or binding them to a cross), proposed by Lemmens under the category of instrument-verbs, occupies a marginal position because it embeds instruments like nails, on the one hand, and the act of putting to death, which is carried out by means of nailing to a cross, on the other hand. Thus, the definitions illustrate that each of these verbs performs the act of killing by using a certain instrument, i.e. a wire, a pointed weapon, a bullet/an arrow, a rope, a knife, poison, and a cross respectively. Additionally, all the verbs mentioned above carry the nuclear meaning of "to cause to die".

The second subcategory incorporates the motivation features, i.e. the semantics of these verbs denotes or embeds the stimulus of killing. Analyzing this category, it becomes clear that usage of the verbs mentioned below is limited only to people with cer- 
tain status and strictly dependent on the context, entailing one of the features of killing people who stand out with their reputation, faith, crime history, etc. However, the nuclear meaning to cause to die is still preserved. The verbs under this subcategory are:

- assassinate (to murder an important person for political or religious reasons),

E.g. A prime minister who sought to push an unpopular agreement through was assassinated by a religious nationalist in March 1951. (BNC 2007:G3R 911)

E.g. On 2nd June 1914, the Archduke Franz Ferdinand and his wife, were assassinated by a Bosnian Serb and that triggered a series of events that led to the outbreak of war on 4th, August 1914 - the war that became known as The Great War. (BNC 2007:ALY 613)

- execute (to carry out a sentence of death),

E.g. He executed, imprisoned or dispossessed many of his own relatives to ensure the containment of their territorial ambitions and safeguard against any attempted seizure of the throne. (BNC 2007:EF2 550)

E.g. Chinese authorities have executed a bank accountant who embezzled more than $\$ 175,000$ in the country's first such case of computer fraud, the Xinhua Daily Telegraph newspaper reported yesterday... (BNC 2007:CPK 343)

- lynch (to kill someone for an alleged offence).

E.g. He was to become one of the leading advisers of the Merovingian king Theudebert I, and was lynched after the king's death as being responsible for taxing the Franks. (BNC 2007:HY0 387)

E.g. On April 23, police fired upon demonstrators who attacked a Kathmandu police station, and six policemen were lynched by angry crowds. (BNC 2007:HKT 144)

- martyr (to kill someone because of their beliefs),

E.g. At Glasgow Cross near Gallowgate where, once, men had hung, and where a saint, John Ogilvie, was martyred. (BNC 2007:BNC 499)

E.g. Peter was probably martyred in Rome during the persecutions of Nero in 64-5 $A D$. (BNC 2007:CEJ 346)

The third basic subcategory to be considered, the manner features, is by far the largest and incorporates different manners of killing. Despite the uniting criterion of the manner, the components of this subcategory can be cross-classified on the basis of similar definitions. The following examples illustrate few verbs that denote the act of killing in an elaborate way:

- behead (to kill or execute by decapitation),

E.g. Saudi Arabia yesterday publicly beheaded four people - two Saudis and two Indians - convicted of murder, taking the total number of people beheaded this year to 99. - Reuter. (BNC 2007:AAT 83)

E.g. When the clumsy plotting of the Queen of Scots against Elizabeth finally exasperated the English beyond endurance, Mary was beheaded at Fotheringhay. (BNC 2007:EF2 1194)

- butcher (to kill people in a very cruel and violent way), 
E.g. The Irish rebels were butchered without mercy. (BNC 2007:B1X 241)

E.g. Millions of men had been butchered during the First World War, and in post-war years, the ratio of births, as I understand it, was four to one in favour of baby girls. (BNC 2007:BN3 1420)

- massacre (to kill a large number of people, especially in a cruel way),

E.g. Red Cross officials are trying to confirm reports that 1,200 people had been massacred at a Serb detention camp at Lukavac. (BNC 2007:CH6 7186)

E.g. For the first time in European history the Jews were not only persecuted, they were massacred. (BNC 2007:BMV 380)

- slaughter (to kill a large number of people or animals violently),

E.g. Nine hundred prisoners were slaughtered on the battlefield and as Arundell was escorted from Cornwall to the Tower of London, he saw many a miserable peasant dangling from a crossroads gibbet. (BNC 2007:B0G 692)

E.g. In the early 1980s, the army slaughtered thousands of Guatemalans in a brutal counter-insurgency campaign. (BNC 2007:CRC 1517)

- slay (to kill somebody in a war or a fight)

E.g. And in the year 1037 Ferdinand slew Bermudo the King of Leon in battle, who was his wife's brother, and conquered his kingdom, and succeeded to it in right of his wife Doña Sancha. (BNC 2007:ASW 472)

E.g. In battle, Aenarion slew foes beyond reckoning. (BNC 2007:CM1 581)

Other verbs under this subcategory denote the act of killing by imposing deficiency of vital needs: asphyxiate (lack of air), decapitate (absence of a vital organ), drown (lack of air), famish (lack of food), smother (lack of air, i.e. to kill somebody by covering their face so that they cannot breathe), stifle (lack of respiration), strangle (lack of air), suffocate (lack of air), throttle (lack of air) and starve (lack of food).

Finally, there is a group of kill-verbs, which do not fall under any of the aforementioned features; thus, constituting a group of verbs with the features on periphery. These verbs are usually used in formal speech as a euphemistic way of denoting killing. It is also worth mentioning that Oxford English Dictionary grants to the verbs to dispatch and to liquidate the definitions "to kill a person or an animal" and "to get rid of, especially by killing" respectively. A group of verbs with the features on periphery constitute the following verbs:

- eliminate (to kill somebody, especially an enemy or opponent),

E.g. By 1614 he had eliminated Hideyoshi's heir and overcome the final military opposition to his hegemony. (BNC 2007:EE2 45)

- exterminate (to kill all the members of a group of people or animals),

E.g. The original breeding population of this raptore in Sussex was exterminated in the interests of game preserving during the 19th century, breeding being last recorded in Ashdown Forest in 1882. (BNC 2007:B31 1452)

E.g. In the course of about twenty-four hours Ed Riverton had been brutally exterminated in Finland - and his wife had been eliminated with equal brutality in East Anglia, over a thousand miles away. (BNC 2007:CN3 325) 
Considering the variety of features of English causative verbs, there can be many potential criteria for classification, which may lead to further elaboration on the classification suggested in this article. If a comprehensive classification has to be developed, it must be based on the most important feature, i.e. one characteristic that both unites the whole class of causatives and divides them into subgroups. That one main feature of killverbs is their nuclear meaning "to cause to die". Firstly, verbs must be categorized according to their relation to the nuclear meaning. Secondly, they must be subcategorized and compared with each other based on the additional features they denote parallel with the nuclear one. The verbs can be further cross-categorized and cross-compared, but this should be performed not within the scope of the main classification.

To summarize, it is undeniable that even though the verbs mentioned above express killing, their use is limited to specific contexts. The so-called "feel for the language" is strongly connected to the right choice of seemingly similar words. Mutual characteristics of verbs must also be taken into consideration to determine the possibilities of substitution. It is important to note that the context plays a focal role in substitution and it can prevail over some characteristics of the causative verbs, and emphasize the others. Overall, the new classification suggested in this article is to establish the nuclear meaning "to cause to die" as an axis of classification. The classification unites the verbs with the same nuclear meaning and emphasizes their additional features at the same time. To clarify, verbs like to eliminate are strongly dependent on the context and formal/informal style of the speech. In informal speech the verb to eliminate might not have the meaning of "to cause to die", while in formal speech the verb will be treated as a euphemism for other kill-verbs, i.e. to kill, to murder. The suggested classification of semantic classes of lexical causative verbs cannot be considered exhaustive. As linguistic data suggest, Modern English employs structured classifications of causative verbs that are already being analyzed from the surface-syntactic and deep-semantic viewpoints. All verbs under this classification have been classified according to their meanings and additional features, such as the expressed or embedded instrument, motivation and manner. However, a detailed classification of kill-verbs will be a new ground for further research. All theoretical assertions made in this article are subject to further empirical investigation because causatives constitute an undiscovered domain, which has the potential to reveal new findings about structures and usage in different languages.

\section{References:}

1. The British National Corpus, Version 3. (2007) Distributed by Oxford University Computing Services on behalf of the BNC Consortium. URL: $<$ http://www.natcorp.ox.ac.uk $>$.

2. Dowty, D. (1979) Word Meaning and Montague Grammar. Dordrecht: Reidel.

3. Frawley, W. (1992) Linguistic Semantics. Hillsdale: Lawrence Erlbaum associates.

4. Halliday, M.A.K. (1994) An Introduction to Functional Grammar. London: Edward Arnold. 
5. Khachatryan, R. (2009) Ways of Expressing Causation in Modern English. // Armenian Folia Anglistika. Yerevan: Lusakn.

6. Kemmer, S. \& Verhagen, A. (1994) The Grammar of Causatives and the Conceptual Structure of Events. Cognitive Linguistics. 5(2), (115-156).

7. Lemmens, M. (1998) Lexical Perspectives on Transitivity and Ergativity: Causative Constructions in English. Amsterdam and Philadelphia: John Benjamins.

8. Levin, B. (1992) English Verb Classes and Alternations. Chicago: University of Chicago Press

9. Levin, B.; Comrie, E.; Polinsky, M. (Eds.) (1993) More on the Typology of Inchoative/Causative Verb Alternations. // Causatives and Transitivity. Amsterdam and Philadelphia: John Benjamins.

10. Levin, B. and Rappaport, H.M. (1995) Unaccusativity: At the Syntax-Lexical Semantics Interface. Cambridge: The MIT Press.

11.Longman Dictionary of Contemporary English. Available online $<$ http://www.ldoceonline.com $>$.

12. Oxford English Dictionary. <http://oxforddictionaries.com>.

13. Talmy, L.; Shopen, T. (Eds.). (1985) Lexicalization Patterns: Semantic Structures in Lexical Forms. // Language Typology and Syntactic Description. Vol. III: Grammatical Categories and the Lexicon. Cambridge: CUP.

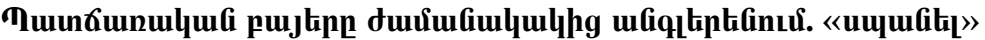

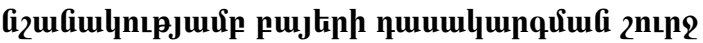

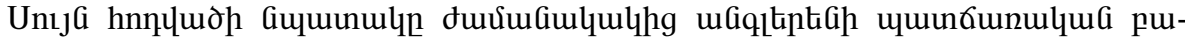

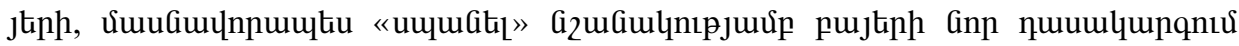

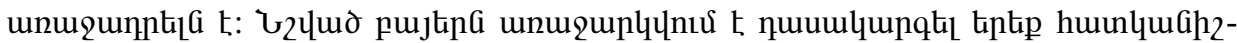

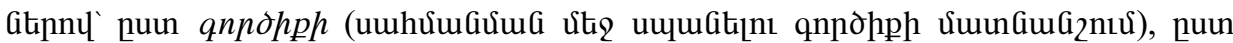

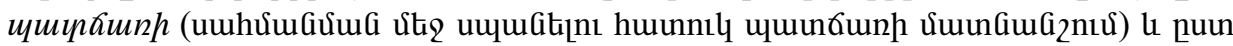

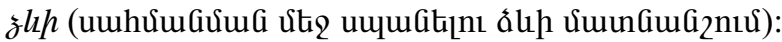

